\title{
STRATEGI PENGEMBANGAN TAMAN WISATA KUM KUM SEBAGAI WISATA EDUKASI DI KOTA PALANGKARAYA
}

\author{
Evi Fitriana* \\ * Jurusan Pendidikan Geografi FKIP Universitas PGRI Palangka Raya
}

\begin{tabular}{l}
\hline \hline INFO ARTIKEL \\
\hline Riwayat Artikel: \\
Diterima: $25-1-2018$ \\
Disetujui: $14-5-2018$
\end{tabular}

\section{Kata kunci:}

pengembangan, wisata,

SWOT

\author{
Alamat Korespondensi: \\ Evi Fitriana \\ Jurusan Pendidikan Geografi \\ Universitas PGRI Palangka Raya \\ Jl. Hiu Putih KM 7, Palangka Raya \\ E-mail: eviza27@gmail.com
}

\begin{abstract}
ABSTRAK
Abstrak: Rendahnya perhatian pemerintah daerah dalam rangka pengembangan kepariwisataan menjadi latar belakang penelitian ini. Masalah yang muncul adalah strategi pengembangan taman wisata Kum Kum di Kota Palangka Raya masih belum jelas. Penelitian ini bertujuan untuk (1) menganalisis faktor-faktor internal dan eksternal yang mendukung dan menghambat dalam pengembangan Taman Wisata Kum Kum, dan (2) menentukan strategi pengembangan kawasan wisata Taman Wisata Kum Kum yang terletak di Kelurahan Pahandut, Kecamatan Pahandut, Kota Palangka Raya. Penelitian ini menggunakan metode penelitian deskriptif kuantitatif dengan menggunakan alat analisis SWOT (Strenghts, Weaknes, Opportunities, Threats). Data dikumpulkan melalui studi kepustakaan, observasi serta wawancara dengan Dinas Pariwisata, Bappeda, camat, lurah, tokoh masyarakat, masyarakat dan pengunjung. Berdasarkan hasil penelitian maka dapat disimpulkan strategi pengembangan taman wisata Kum Kum antara lain membangun sarana prasarana seperti alat angkut dan sarana akomodasi, membuat atraksi wisata dan promosi obyek wisata, mengembangkan produk wisata, serta melibatkan pemerintah dan swasta dalam pengelolaan wisata.
\end{abstract}

\section{PENDAHULUAN}

Pariwisata merupakan salah satu sektor industri yang potensial sebagai strategi pengembangan suatu daerah. Industri pariwisata memberi peran yang penting bagi perekonomian suatu negara karena memberikan tambahan devisa sehingga penerimaan negara meningkat, selain itu dapat menambah lapangan pekerjaan bagi masyarakat sekitar objek wisata misalnya dengan adanya pedagang-pedagang kecil seperti pedagang makanan ringan dan penjual souvenir yang dapat mengurangi pengangguran dan kemiskinan (Yoeti, 2008).

Sektor kepariwisataan Indonesia terbukti mampu bertahan menghadapi tekanan badai krisis global. Melalui program Visit Indonesia Year 2009 sektor pariwisata berhasil menjaring dan mendatangkan wisatawan mancanegara sebanyak 6,5 juta orang dengan perolehan devisa USD7,5 juta di mana hasil tersebut sesuai dengan target yang dicanangkan oleh pemerintah (BPS, 2010). Sebagai sebuah industri, terdapat banyak hal yang tercakup di 
dalam pariwisata seperti transportasi, akomodasi, jasa, dan atraksi yang menyerap banyak tenaga kerja. Pariwisata juga meningkatkan peran sektor-sektor pendukung di pemerintahan maupun swasta seperti biro perjalanan wisata, industri cinderamata, obyek dan daya tarik wisata, hotel, restoran dan sumber daya manusia.

Pariwisata merupakan salah satu industri gaya baru yang mampu menyediakan pertumbuhan ekonomi yang cepat dalam hal kesempatan kerja, pendapatan, taraf hidup, dan mengaktifkan sektor produksi lain di dalam negara penerima wisatawan (Wahab, 1997). Seiring dengan semakin meningkatnya kesadaran masyarakat terhadap kualitas hidup, dalam perkembangannya kebutuhan rekreasi ini telah banyak mengalami perubahan orientasi. Masyarakat yang semakin peduli terhadap masalah-masalah kerusakan lingkungan dan hancurnya tatanan kehidupan masyarakat tradisional, melirik pada hal-hal yang lebih natural.

Indonesia sebagai negara yang memiliki kekayaan sumberdaya alam hayati menjadi salah satu alternatif wisatawan asing untuk melepaskan kejenuhan mereka terhadap hiruk pikuk industrialisasi. Potensi sumber daya alam hayati dan ekosistemnya perlu dikembangkan dan dimanfaatkan sebesar-besarnya bagi kesejahteraan rakyat melalui upaya konservasi sumber daya alam hayati dan ekosistemnya, sehingga tercapai keseimbangan antara perlindungan, pengawetan, dan pemanfaatan secara lestari.

Dampak positif pengembangan pariwisata dapat dilihat dari pembangunan sarana dan prasarana pariwisata yang menyerap banyak tenaga kerja (Andayani,dkk: 2012). Pengembangan objek wisata harus mempertimbangkan kepentingan nasional, regional dan lokal mengingat perkembangan pariwisata akan menjadi sektor yang strategis dalam kerangka otonomi daerah.

Pariwisata di Kota Palangka Raya tersebar sesuai dengan potensi geografis di wilayah ini. Wilayah Palangka Raya dilewati oleh sebuah sungai besar yaitu sungai Kahayan yang juga merupakan salah satu faktor eksternal pendukung potensi wisata (Bappeda Kota Palangka Raya: 2011). Salah satu objek wisata di Kota Palangka Raya yang mudah dijangkau adalah Taman Wisata Kum Kum. Objek wisata ini menawarkan tempat rindang yang menyediakan gubuk-gubuk dari kayu dan dirindangi oleh pohon-pohon karet. Taman Wisata Kum Kum juga disebut sebagai kebun binatang kecil karena terdapat beberapa binatang khas Kalimantan seperti buaya Kalimantan, burung elang, musang, kelinci, marmut, dan monyet. Disamping kelebihan, terdapat pula kekurangan yang perlu dibenahi oleh pengelola maupun pemerintah Kota Palangka Raya.

Secara menyeluruh objek wisata ini perlu dilakukan upaya-upaya pengembangan terencana sebagai pelindung dan pelestari lingkungan. Pengembangan pariwisata yang sangat memungkinkan untuk kawasan ini adalah dengan menjadikannya sebagai suatu kawasan ekowisata. Ekowisata merupakan kegiatan wisata yang menaruh perhatian besar terhadap kelestarian sumber daya pariwisata. Masyarakat ekowisata inter-nasional mengartikannya sebagai perjalanan wisata alam yang bertanggung jawab dengan cara mengkonservasi lingkungan dan meningkatkan kesejahteraan masyarakat lokal (Garrod and Wilson, 2003).

Mengingat besarnya potensi Taman Wisata Kum Kum untuk dikembangkan menjadi objek wisata khususnya wisata edukasi berbasis alam, maka perlu dilakukan identifikasi faktor internal dan eksternal yang mempengaruhi pengembangan objek wisata ini. Berdasarkan faktor internal dan eksternal tersebut maka selanjutnya akan dikembang-kan strategi pengembangan wisata di Taman Wisata Kum Kum. Tujuan dilaksanakan penelitian ini adalah mengidentifikasi faktor internal dan faktor eksternal yang mempengaruhi 
Jurnal Pendidikan Geografi:

Kajian, Teori, dan Praktik dalam Bidang Pendidikan dan Ilmu Geografi

Tahun 23, Nomor 2, Jun 2018, Hal 94-106

pengembangan wisata edukasi di Taman Wisata Kum Kum dan mengembangkan strategi pengembangan wisata wisata edukasi di Taman Wisata Kum Kum.

\section{METODE}

Rancangan dalam penelitian ini adalah penelitian deskriptif dengan pendekatan kuantitatif. Objek studinya adalah Taman Wisata Kum Kum Kota Palangka Raya, Kalimantan Tengah. Penelitian ini mengarah pada pengungkapan suatu masalah atau keadaan sebagaimana adanya dan mengungkapkan fakta-fakta yang ada, terkadang diberikan interpretasi atau analisis. Penelitian ini dilaksanakan melalui dua tahap. Tahap pertama melakukan identifikasi faktor internal (stregth dan weakness) dan eksternal (opportunity dan treath).

Teknik analisis yang digunakan dalam penelitian ini adalah analisis deskripsi dan analisis SWOT. Analisis SWOT dilakukan untuk mengidentifikasi secara sistematik antara kekuatan dan kelemahan dari faktor internal serta peluang dan ancaman dari faktor eksternal yang dihadapi, sehingga dapat dibuat suatu alternatif strategi. Analisis SWOT dipilih karena dapat mengetahui situasi wisata dengan mengidentifikasi faktor eksternal dan internal yang berpengaruh pada objek wisata serta mengetahui peluang dan kekuatan yang dimiliki untuk menentukan rencana serta mengatasi kelemahan dan ancaman dengan rencana perbaikan. Teknik pengambilan data dalam penelitian ini terdiri dari observasi, wawancara, dan dokumentasi (foto, peta).

Lokasi penelitian ini adalah Taman Wisata Kum Kum di Kota Palangkaraya. Data yang digunakan bersumber dari data primer dan data sekunder. Data primer diperoleh melalui observasi, wawancara, dan dokumentasi yang dilakukan dengan Dinas Pariwisata, Bappeda, camat, kepala desa, tokoh masyarakat, masyarakat dan pengunjung. Data sekunder diperoleh melalui Badan Pusat Statistik (BPS), BAPPEDA dan Dinas Pariwisata, Kantor Camat dan Kepala Desa. Untuk menentukan strategi pengembangan objek wisata dilakukan analisis SWOT (Strengths/ kekuatan, Weakness/ kelemahan, Opportunities/ peluang, dan Threats/ Ancaman).

Informan dalam penelitian ini terdiri atas (1) Kepala Bidang Kepariwisataan Dinas Pariwisata Kota Palangka Raya, (2) BAPPEDA Kota Palangka Raya bidang Pemerintahan Sosial dan Budaya, (3) Camat Pahandut, (4) Lurah Pahandut, (5) Tokoh masyarakat (6) Masyarakat sekitar objek wisata, (7) Pengunjung objek wisata. berikut:

Teknik analisis data dalam penelitian ini dilakukan melalui beberapa tahap sebagai

(1) Reduksi; Data yang diperoleh dikumpulkan dan diseleksi antara data utama dan data pelengkap. Kemudian diuraikan, difokuskan pada hal-hal yang penting secara sistematis sehingga lebih mudah dimengerti.

(2) Model data (data display); merupakan suatu kumpulan informasi yang tersusun dari pendeskripsian dan pengambilan tindakan. Bentuk dari model data bersifat naratif dengan mengunakan matriks SWOT. Matriks SWOT merupakan alat yang dipakai untuk menyusun strategi pengembangan objek wisata. Matriks SWOT menggambarkan secara jelas peluang dan ancaman yang dihadapi sehingga dapat disesuaikan dengan kekuatan serta kelemahan yang dimiliki pariwisata. Melalui matriks SWOT dapat ditetapkan strategi pengembangan yang tepat. Matriks ini dapat menghasilkan empat sel kemungkinan alternatif strategis, untuk lebih jelasnya dapat dilihat pada tabel 1 di bawah ini: 
Jurnal Pendidikan Geografi:

Kajian, Teori, dan Praktik dalam Bidang Pendidikan dan Ilmu Geografi

Tahun 23, Nomor 2, Jun 2018, Hal 94-106

Tabel 1. Matriks SWOT

\begin{tabular}{lll}
\hline & $\begin{array}{l}\text { Kekuatan } \\
(\text { Strengths })(\mathrm{S})\end{array}$ & $\begin{array}{l}\text { Kelemahan } \\
(\text { Weaknesses })(\mathrm{W})\end{array}$ \\
\hline $\begin{array}{l}\text { Peluang } \\
\text { (Opportunities) }(\mathrm{O})\end{array}$ & Strategi SO & Strategi WO \\
\hline $\begin{array}{l}\text { Ancaman } \\
\text { (Threats) }(\mathrm{T})\end{array}$ & Strategi ST & Strategi WT \\
\hline \multicolumn{3}{c}{ Sumber: Wasistiono, dkk (2007) }
\end{tabular}

Berdasarkan tabel di atas, SO memanfaatkan seluruh kekuatan dengan memperhitungkan peluang, WO memanfaatkan kelemahan dengan memperhatikan peluang, ST memanfaatkan kekuatan dengan memperhatikan ancaman, dan WT memanfaatkan kelemahan dengan memperhatikan ancaman.

(3) Klasifikasi; Data yang telah diperoleh kemudian dikelompokkan sesuai dengan tema-tema yang muncul, sehingga mempermudah dalam analisis.

(4) Kesimpulan; Data yang diperoleh dicari maknanya dan diambil kesimpulan.

\section{Tinjauan Fisik Taman Wisata Kum Kum}

\section{HASIL DAN PEMBAHASAN}

\section{a. Sarana dan Prasarana}

Sarana dan prasarana yang tersedia di taman wisata Kum Kum dan memiliki nilai jual secara ekonomi terdiri dari fasilitas pokok, fasilitas pelengkap, fasilitas penunjang, prasarana umum dan prasarana sosial jenis sarana dan prasarana tersebut antara lain warung makanan dan minuman, gazebo tempat istirahat, taman bermain, loket masuk, tempat parkir, air bersih, toilet, dan pusat informasi.

\section{b. Aksesbilitas}

Jaringan jalan menuju taman wisata Kum Kum bervariasi yaitu mulai dari bundaran besar Kota Palangka Raya menyeberangi sungai Kahayan dengan melewati jembatan. Jalan menuju taman wisata Kum Kum merupakan jalan kelas I dengan panjang jalan $+3 \mathrm{~km}$, lebar jalan + 6-8 m dan perkerasan berupa aspal hotmix. Dari jembatan Kahayan menuju lokasi objek wisata ditempuh dengan jarak $+1,5 \mathrm{~km}$. Kondisi jaringan jalan yang baik dengan dilengkapi marka yang memadai serta rambu-rambu lalu lintas memudahkan wisatawan untuk mengakses taman wisata ini.

\section{c. Daya Tarik Wisata}

Bentuk-bentuk atraksi atau kegiatan yang telah ada di taman wisata Kum Kum diantaranya adalah kegiatan yang bersifat something to do, something to see dan something to buy. Kegiatan yang bersifat something to do diantaranya kegiatan menikmati keindahan alam, memberi makan beruang madu, memberi makan buaya, kegiatan bermain di taman bermain, berkeliling mengunjungi kandang-kandang hewan, dan bersantai di gazebo-gazebo yang telah disediakan. Sedangkan kegiatan yang bersifat something to buy diantaranya berbelanja makanan dan minuman di warung/kedai yang ada di lokasi wisata.

Daya tarik wisata yang dapat dikembangkan antara lain: Pentas Seni Tari Tradisional; sasana pemancingan; produksi amplang; dan menu khas kota Palangkaraya seperti tumis kelakai, ketupat kandangan, ikan haruan bumbu merah, ikan patin masak kuning dan sayur umbut rotan.

\section{d. Aktivitas ekonomi masyarakat}

Mata pencaharian masyarakat di kelurahan Pahandut di sekitar lokasi wisata sebagian besar sebagai pedagang/ wiraswasta. Sedangkan kegiatan lain yang ditekuni oleh 
Jurnal Pendidikan Geografi:

Kajian, Teori, dan Praktik dalam Bidang Pendidikan dan Ilmu Geografi

Tahun 23, Nomor 2, Jun 2018, Hal 94-106

masyarakat sekitar adalah buruh bangunan, nelayan sungai, jasa, dan pegawai negeri sipil (Kelurahan Pahandut, 2015).

\section{Tinjauan Wisatawan}

\section{a. Tipologi wisatawan}

Tipologi wisatawan di taman wisata Kum Kum dapat dilihat dari aspek karakter personal, mata pencaharian, tingkat penghasilan, asal wisatawan, asal informasi tentang kawasan wisata, tujuan kunjungan, frekuensi kedatangan, pengeluaran wisatawan, tempat makan, dan moda transportasi yang digunakan.

\section{b. Persepsi wisatawan}

Persepsi wisatawan terhadap taman wisata Kum Kum dapat diketahui dari beberapa aspek, yaitu daya Tarik objek wisata, kondisi umum kawasan wisata dan kondisi sarana prasarana wisata Kum Kum. Berdasarkan wawancara dengan wisatawan, mayoritas memberikan persepsi terhadap taman wisata Kum Kum untuk lebih berinovasi agar lebih menarik wisatawan dari luar daerah.

\section{c. Pengelolaan}

Pengelolaan taman wisata Kum Kum dikelola oleh Dewan Adat Dayak yang berada di bawah tanggung jawab Dinas Kebudayaan dan Pariwisata Pemerintah Daerah Kota Palangka Raya.

\section{Analisis Kebijakan}

Kebijakan yang diterapkan untuk objek wisata Kum Kum didasarkan pada Rencana Induk Pengembangan Pariwisata Kota Palangka Raya tahun 2017-2028 seperti pada tabel 2.

Tabel 2. Analisis Kebijakan Objek Wisata Kum Kum

\begin{tabular}{|c|c|c|}
\hline No & Kebijakan & Analisis \\
\hline 1 & $\begin{array}{l}\text { Strategi pengembangan KSP Pahandut dengan tema pengembangan } \\
\text { pariwisata rekreatif: } \\
\text { - Wisata kuliner } \\
\text { - Wisata keluarga }\end{array}$ & $\begin{array}{l}\text { Strategi pengembangan yang belum dilaksanakan menjadi } \\
\text { indikasi masih rendahnya perhatian pemerintah untuk } \\
\text { meningkatkan fasilitas utama dan penunjang taman wisata Kum } \\
\text { Kum }\end{array}$ \\
\hline 2 & \begin{tabular}{llll}
\multicolumn{3}{l}{ Rencana peningkatan kapasitas dan peran masyarakat: } & \\
- & $\begin{array}{l}\text { meningkatkan keterlibatan } \\
\text { pengembangan kepariwisataan }\end{array}$ & masyarakat & dalam \\
- $\begin{array}{l}\text { menguatkan kelembagaan } \\
\text { pengembangan pariwisata. }\end{array}$ & masyarakat & dalam \\
\end{tabular} & $\begin{array}{l}\text { Keterlibatan masyarakat dalam pengembangan wisata melalui } \\
\text { pengadaan ketrampilan membantu meningkatkan kegiatan } \\
\text { ekonomi masyarakat sehingga menciptakan ide-ide kreatif } \\
\text { masyarakat }\end{array}$ \\
\hline 3 & $\begin{array}{l}\text { Rencana pernbangunan fasilitas dalam mendukung pengembangan } \\
\text { KSP: }\end{array}$ & $\begin{array}{l}\text { Sesuai dengan peningkatan jumlah pengunjung, fasilitas utama } \\
\text { dan penunjang yang sudah ada belum dioptimalkan sehingga } \\
\text { kebutuhan pengunjung belum terpenuhi. }\end{array}$ \\
\hline 4 & Rencana pengembangan moda transportasi & $\begin{array}{l}\text { Pentingnya pengadaaan sistem trasportasi yang mudah } \\
\text { dijangkau oleh wisatawan dari luar daerah }\end{array}$ \\
\hline
\end{tabular}

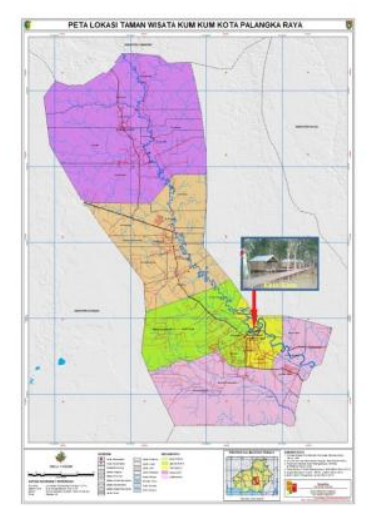

Gambar 1. Peta Lokasi Taman Wisata Kum Kum 
Jurnal Pendidikan Geografi:

Kajian, Teori, dan Praktik dalam Bidang Pendidikan dan Ilmu Geografi

Tahun 23, Nomor 2, Jun 2018, Hal 94-106

\section{Analisis Kawasan Wisata}

\section{a. Analisis supply demand}

Hasil penilaian supply taman wisata Kum Kum menunjukkan nilai 14 yang berarti taman wisata ini memiliki penawaran wisata yang baik dari aspek keanekaragaman objek wisata, sarana prasarana, dan kondisi lingkungan yang masih alami. Berdasarkan hasil perhitungan, nilai demand taman wisata Kum Kum adalah 12 yang artinya permintaan pengunjung terhadap peningkatan pelayanan kawasan wisata tersebut tinggi.

\section{b. Analisis linkage system}

Analisis linkage system digunakan untuk mengetahui keterkaitan dengan objek wisata lain yang berada di sekitar kawasan maupun yang berada pada jalur rute perjalanan menuju taman wisata Kum Kum. Berdasarkan rute perjalanan, terdapat alternatif perjalanan wisata antara lain:

1. Ketika menyeberang di jembatan Kahayan wisatawan dapat mengunjungi objek wisata Tugu Soekarno yang terletak di Jl. S.Parman

2. Ketika berada di Jl. Ahmad Yani, wisatawan dapat mengunjungi Kawasan Kuliner di Flamboyan sekaligus mengikuti kegiatan wisata susur sungai.

3. Oleh-oleh khas Palangka Raya dapat diperoleh wisatawan dengan mengunjungi Pasar Besar yang berada di Jl.Ahmad Yani

4. Di Jalan Dr. Murjani, Kecamatan Pahandut terdapat Sandung yang merupakan bangunan kecil yang khusus diperuntukkan bagi penyimpanan tulang belulang orang yang telah meninggal setelah melalui upacara Tiwah.

5. Objek wisata Museum Balanga juga bisa dikunjungi oleh wisatawan di Jl. Tjilik Riwut $\mathrm{Km} .2,5$

6. Setelah dari Museum Balanga, wisatawan juga dapat mengunjungi Taman Wisata Fantasi Beach yang dapat dijangkau kira-kira 20 menit.

7. Objek wisata Alam Bukit Tangkiling juga dapat dikunjungi wisatawan setelah mengunjungi Taman Wisata Fantasi Beach.

Analisis linkage system ini digunakan untuk menganalisis hubungan antar sektor yang berpengaruh dalam pengembangan pariwisata Kum Kum. Sektor yang berpengaruh adalah sektor jasa, perdagangan, perhubungan, dan industri.

\section{c. Analisis partisipatif}

Para pihak berwenang yang mempengaruhi keberadaan kawasan taman wisata Kum Kum antara lain Dewan Adat Dayak, Pemerintah Daerah Kota Palangka Raya melalui Dinas Kebudayaan dan Pariwisata serta dinas terkait, Pemerintahan Tingkat Kecamatan Jekan Raya, Kecamatan Bukit Batu, Biro atau penyedia jasa (travel, penginapan, dan akomodasi) dan masyarakat sekitar.

\section{d. Analisis prediksi wisatawan}

Perkembangan wisatawan domestik maupun wisatawan mancanegara yang mengunjungi taman wisata Kum Kum diketahui rata-rata pertumbuhan jumlah kunjungan wisatawan sebesar 8,43\%tahun. Berdasarkan angka pertumbuhan tersebut dapat diprekdisikan jumlah kunjungan wisatawan ke kawasan taman wisata pada tahun tahun 2016 sebanyak 154.903 pegunjung dan pada tahun 2021 sebanyak 214.102 pengunjung.

\section{e. Analisis SWOT}

Strategi pengembangan objek wisata merupakan upaya dan usaha-usaha dalam mengembangkan objek wisata ke arah yang lebih maju. Dalam strategi pengembangan diperlukan identifikasi kelengkapan unsur-unsur pariwisata. Unsur-unsur pariwisata berguna dalam menentukan kekuatan, kelemahan, peluang dan ancaman desa sehingga dapat 
dilakukan strategi yang tepat dalam pengembangan. Untuk mengetahui kekuatan, kelemahan, peluang dan ancaman desa maka peneliti melakukan wawancara.

Informan dalam penelitian ini adalah Dinas Pariwisata Kota Palangka Raya, BAPPEDA Kota Palangka Raya, Camat Pahandut, Lurah Pahandut, Tokoh masyarakat, masyarakat sekitar objek wisata, dan Pengunjung objek wisata sehingga diperoleh informasi yang detail, lengkap dan akurat. Para informan memiliki pandangan yang berbeda-beda terhadap pengembangan yang akan dilakukan di taman wisata Kum Kum.

Berdasarkan hasil wawancara diperoleh informasi tentang kekuatan, kelemahan, peluang dan ancaman yang dimiliki oleh taman wisata Kum Kum. Kekuatan yang dimiliki taman wisata Kum Kum antara lain: suasana objek wisata yang masih asri diselingi pohonpohon yang rindang, kesejukan udara menjadi salah satu daya tarik wisatawan, adanya berbagai satwa dan taman bermain mini menjadikan taman wisata ini sebagai objek wisata pendidikan bagi anak-anak. Lokasi taman wisata Kum Kum mudah dijangkau dari pusat kota Palangka Raya. Objek wisata Kum Kum sudah termasuk salah satu objek wisata yang aman, karena tidak ada kasus pencurian, tindak kekerasan, perkelahian, dan aktifitas pengamen yang terkadang membuat pengunjung merasa terganggu.

Kelemahan yang muncul di taman wisata Kum Kum ini yang harus diperhatikan. Kelemahan suatu objek wisata merupakan alat untuk mengevaluasi pengembangan suatu objek wisata untuk menjadi lebih baik. Kelemahan dari taman wisata Kum Kum ini adalah minimnya fasilitas umum seperti toilet dan mushola. Tidak terawatnya fasilitas di taman bermain anak berdampak pada ketidaknyamanan pengunjung yang mengajak anak-anak. Tidak ada peta dan informasi satwa yang ada di lokasi wisata membuat bingung wisatawan dari luar daerah. Masih kurangnya sarana pemeliharaan dan perawatan satwa serta minimnya fasilitas kesehatan satwa. Disamping itu juga masih minimnya fasilitas pengelolaan limbah.

Transportasi khusus atau angkutan umum lainnya yang tidak ada ke lokasi objek wisata membuat akses pengunjung dari luar kota maupun wisatawan mancanegara menjadi terhambat. Hal ini membuat kurangnya kunjungan wisatawan dari luar propinsi dan wisatawan mancanegara. Keterbatasan atraksi pada objek wisata Kum Kum juga menjadikan objek wisata ini belum mampu menahan pengunjung untuk berlama-lama di lokasi wisata. Pengunjung datang dan pergi setelah mengikuti rute, berfoto-foto, makan minum di kedai, dan selesai melepas lelah di gazebo. Sebagian besar pengunjung tidak memiliki keinginan untuk kembali lagi dalam waktu yang singkat. Dengan singkatnya kunjungan wisatawan maka tidak ada minat untuk berbelanja di lokasi objek wisata. Hal ini ditambah dengan belum terwujudnya wisatawan yang sadar lingkungan. Tidak semua pengunjung membuang sampah di tempat yang telah disediakan oleh pengelola objek wisata. Hal yang paling penting adalah peran aktif pemerintah, masyarakat, pengelola dan pengunjung untuk mengembangkan taman wisata Kum Kum.

Peluang adalah kemampuan yang dimiliki suatu daerah untuk dapat dimanfaatkan dan berkembang di masa yang akan datang. Peluang ini bertujuan untuk memajukan objek wisata. Adapun peluang yang dimiliki oleh taman wisata Kum Kum termasuk pada kawasan strategis dari fungsi dan daya dukung lingkungan. Sehingga arah pengembangan taman wisata Kum Kum termasuk salah satu perencanaan yang diutamakan.

Terdapat rencana pemerintah kota untuk mengembangkan pariwisata di wilayah Pahandut yang tercantum dalam Perda Kota Palangka Raya No.11 tahun 2017 tentang Rencana Induk Pembangunan Kepariwisataan Kota Palangka Raya tahun 2017-2028. Perda ini memberi kesempatan kepada pemerintah, masyarakat dan pelaku industri untuk 
Jurnal Pendidikan Geografi:

Kajian, Teori, dan Praktik dalam Bidang Pendidikan dan Ilmu Geografi

Tahun 23, Nomor 2, Jun 2018, Hal 94-106

mengembangkan potensi wisata dan sumber daya alam yang ada dengan memanfaatkan kemajuan teknologi informasi serta letak geografis.

Berdasarkan peluang tersebut maka muncul ancaman dari luar yang dapat mengancam pengembangan taman wisata Kum Kum ini. Adapun ancamannya adalah berkembangnya objek wisata lain yang meningkatkan persaingan, dan berkembang-nya variasi-variasi atraksi yang ditawarkan oleh objek wisata lain yang dapat menarik pengunjung. Untuk dapat bersaing dengan objek wisata lainnya maka diperlukan inovasiinovasi untuk menarik pengunjung, sehingga dibutuhkan sumber daya manusia yang handal, kreatif, inovatif dan berkualitas.

Kerusakan lingkungan akibat tidak tepatnya pengembangan kawasan wisata merupakan ancaman yang disebabkan oleh manusia dan alam. Kesadaran pengunjung untuk ikut menjaga objek wisata merupakan hal penting agar sesama pengunjung memperoleh kenyamanan dan menjaga keasrian objek wisata. Pengembangan wisata nantinya juga perlu memperhatikan kelestarian lingkungan.

Strategi pengembangan taman wisata Kum Kum dapat dilihat pada tabel berikut ini:

Tabel 3. Kekuatan (Strength-S)

\begin{tabular}{ll}
\hline \multicolumn{1}{c}{ Kekuatan (Strength-S) } \\
\hline 1. Objek wisata masih asri \\
2. Adanya berbagai satwa \\
3. Ada taman bermain untuk anak \\
4. Lokasi mudah dijangkau dari pusat kota \\
5. Termasuk salah satu objek wisata yang aman.
\end{tabular}
Kum Kum.

Kekuatan tersebut merupakan faktor pendorong dalam pengembangan taman wisata

Tabel 4. Kelemahan (Weakness-W)

\begin{tabular}{ll}
\hline \multicolumn{1}{c}{ Kelemahan (Weakness-W) } \\
\hline 1. & Minimnya fasilitas umum seperti toilet dan mushola. \\
2. & Tidak terawatnya fasilitas di taman bermain anak \\
3. & Tidak ada peta dan informasi satwa \\
4. & Kurangnya sarana pemeliharaan dan perawatan satwa \\
5. & Tidak ada transportasi khusus atau angkutan umum ke \\
& lokasi objek wisata \\
6. & Keterbatasan waktu kunjung \\
\hline
\end{tabular}

Kelemahan tersebut bisa diatasi dengan merumuskan strategi pengelolaan oleh pemerintah dengan melibatkan masyarakat, pengunjung dan pelaku industri.

Tabel 5. Peluang (Opportunities-O)

\begin{tabular}{l} 
Peluang (Opportunities-O) \\
\hline 1. Taman wisata Kum Kum termasuk pada kawasan strategis \\
dari fungsi dan daya dukung lingkungan \\
2. Adanya rencana pemerintah daerah untuk mengembangkan \\
objek wisata ini \\
3. Adanya Perda ini memberi kesempatan kepada pemerintah, \\
masyarakat dan pelaku industri untuk mengembangkan \\
potensi wisata \\
4. Paket wisata karena berdekatan dengan objek wisata lain \\
5. Penambahan wahana outbond
\end{tabular}


Jurnal Pendidikan Geografi:

Kajian, Teori, dan Praktik dalam Bidang Pendidikan dan Ilmu Geografi

Tahun 23, Nomor 2, Jun 2018, Hal 94-106

Tabel 6. Ancaman (Threats-T)

\begin{tabular}{ll}
\hline \multicolumn{1}{c}{ Ancaman (Threats-T) } \\
\hline 1. & Berkembangnya objek wisata lain \\
2. & Kerusakan lingkungan akibat pengembangan yang tidak \\
memperhatikan lingkungan
\end{tabular}

Berdasarkan penjabaran kekuatan, kelemahan, peluag dan ancaman di atas, kemudian dilakukan pembobotan (1-3) dan pemberian ratting dengan skala Likert (1-5). Setelah itu bobot dikalikan ratting untuk mendapatkan skor. Hasil perhitungan analisis SWOT sebagai berikut:

Tabel7. Faktor Internal (Kekuatan dan Kelemahan)

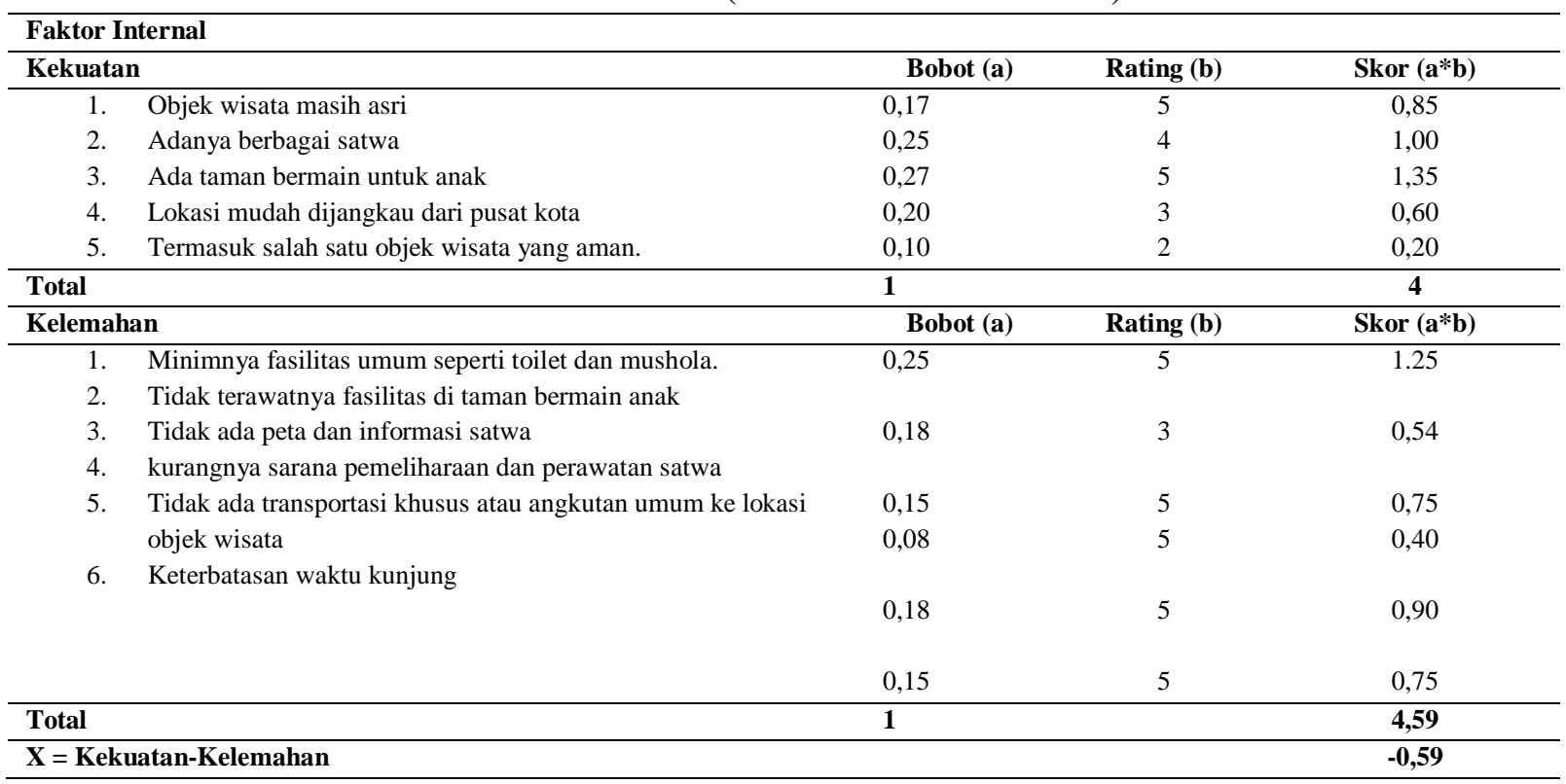

Berdasarkan penghitungan SWOT diperoleh nilai sebesar -0,59. Nilai ini menunjukkan kondisi internal objek wisata Kum Kum. Adapun peluang dan ancaman sebagai berikut:

Tabel 8. Faktor Eksternal (Peluang dan Ancaman)

\begin{tabular}{|c|c|c|c|c|}
\hline \multicolumn{5}{|c|}{ Faktor Eksternal } \\
\hline Peluang & & Bobot (a) & Rating (b) & Skor $(\mathbf{a} * \mathbf{b})$ \\
\hline 1. & Lokasi strategis & 0,17 & 3 & 0,51 \\
\hline 2. & Adanya rencana pemerintah daerah untuk & & & \\
\hline \multirow{4}{*}{3.} & mengembangkan objek wisata ini & 0,10 & 1 & 0,1 \\
\hline & Adanya Perda yang memberi kesempatan kepada & 0,20 & 4 & 0,80 \\
\hline & pemerintah, masyarakat dan pelaku industri untuk & 0,30 & 5 & 1,50 \\
\hline & mengembangkan potensi wisata & 0,22 & 3 & 0,66 \\
\hline 4. & Paket wisata karena berdekatan dengan objek wisata lain & & & \\
\hline 5. & Penambahan wahana outbond. & & & \\
\hline Total & & 1 & & 3,57 \\
\hline \multicolumn{5}{|l|}{ Ancaman } \\
\hline 1. & Berkembangnya objek wisata lain & 0,25 & 5 & 1,25 \\
\hline 2. & $\begin{array}{l}\text { Kerusakan lingkungan akibat pengembangan yang tidak } \\
\text { memperhatikan lingkungan }\end{array}$ & 0,75 & 3 & 2,25 \\
\hline Total & & $\mathbf{1}$ & & $\mathbf{3 , 5 0}$ \\
\hline $\mathbf{Y}=$ Pelua & ng-Ancaman & & & $\mathbf{0 , 0 7}$ \\
\hline
\end{tabular}


Untuk mengetahui letak kuadran strategi yang dianggap memiliki prioritas yang tinggi dan mendesak untuk segera dilaksanakan digunakan formulasi sumbu $\mathrm{X}$ dan $\mathrm{Y}$, dimana sumbu $\mathrm{X}$ adalah EFAS (Peluang-Ancaman) dan sumbu Y adalah IFAS (KekuatanKelemahan) yang dinyatakan dengan nilai sesuai hasil skoring yang diperlihatkan pada gambar berikut.

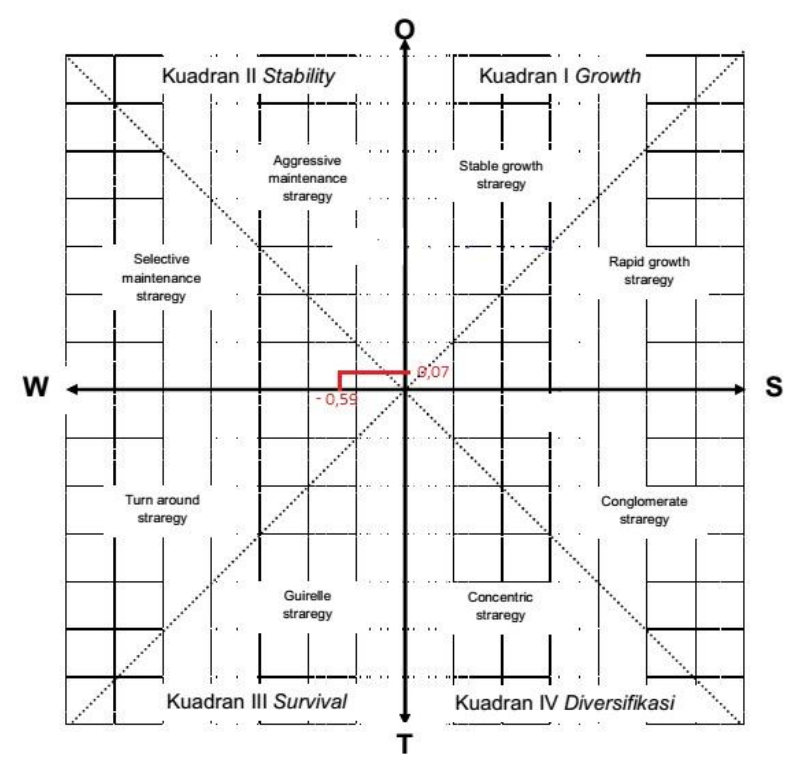

Berdasarkan gambar di atas, strategi yang mendesak untuk dilaksanakan dalam rangka pengembangan taman wisata Kum Kum terletak di kuadran II. Posisi ini menandakan bahwa peluang objek wisata untuk berkembang lebih baik masih ada meskipun menghadapi ancaman. Ancaman tersebut dapat dihadapi dengan mengandalkan kekuatan yang dimiliki oleh taman wisata Kum Kum. Oleh karena itu, pengelola dapat menggunakan alternatif strategi inovasi.

Strategi yang dilakukan untuk pengembangan taman wisata Kum Kum sesuai analisis SWOT menghasilkan empat alternatif yaitu alternatif Strategi SO (menciptakan strategi dengan menggunakan kekuatan untuk memanfaatkan peluang), alternatif Strategi WO (menciptakan strategi yang meminimalkan kelemahan untuk memanfaatkan peluang), alternatif Strategi ST (menciptakan strategi dengan menggunakan kekuatan untuk mengatasi ancaman), dan alternatif Strategi WT (menciptakan strategi yang meminimalkan kelemahankelemahan dan menghindari ancaman).

\section{a. Strategi SO (Strength and Opportunities)}

Strategi SO yaitu strategi yang mengoptimalkan kekuatan (Strength) untuk memanfaatkan Peluang (Oportunities), alternatif dari srategi SO adalah:

1) Membangun dan memperbaiki sarana dan pemeliharaan prasarana wisata

Setiap wisatawan yang mengunjungi objek wisata tentu mmenginginkan lokasi wisata yang menarik untuk dikunjungi. Sarana dan prasarana kepariwisataan sangat berpengaruh terhadap meningkatnya jumlah kunjungan wisatawan ke objek wisata. Jika wisatawan merasa kebutuhannya tercukupi, maka akan menjadi kenangan tersendiri bagi pengujung dan ingin mengunjungi kembali objek wisata tersebut. Oleh karena itu, di sekitar ataupun di kawasan objek wisata perlu dibangun sarana dan prasarana pendukung kegiatan kepariwisataan guna keberlanjutan pariwisata di daerah tersebut, seperti membangun MCK, mushola, lahan parkir, wahana permainan untuk anak-anak, gazebo, dan pengaman 
Jurnal Pendidikan Geografi:

Kajian, Teori, dan Praktik dalam Bidang Pendidikan dan Ilmu Geografi

Tahun 23, Nomor 2, Jun 2018, Hal 94-106

jembatan. Disamping membangun dan mengadakan sarana prasarana, hal yang terpenting adalah pemeliharaan dan perawatan sarana dan prasarana tersebut. Pemeliharaan dilakukan untuk mempertahankan fungsi sarana prasarana.

2) Mengadakan Akomodasi Pariwisata

Akomodasi merupakan rumah sementara untuk beristirahat apabila wisatawan lelah selama berada di daerah yang dikunjungi, baik itu hotel, losmen maupun villa dengan kenyamanan dan pelayanan yang baik dan kebersihan sanitasinya. Semua fasilitas harus sesuai dengan kebutuhan wisatawan. Jumlahnya harus diperhitungkan berdasarkan jumlah dan lamanya wisatawan tinggal ditempat objek wisata.

3) Mengembangkan Atraksi Wisata

Atraksi wisata yang baik harus dapat mendatangkan wisatawan sebanyakbanyaknya, menahan mereka ditempat atraksi dalam waktu yang cukup lama dan memberi kepuasan kepada wisatawan. Atraksi wisata selain yang disediakan oleh alam perlu dibangun atraksi pendamping pariwisata agar suasana dan keadaan objek wisata tidak membosankan. Atraksi yang dapat dibangun di taman wisata Kum Kum misalnya, wahana outbound, flying fox, tempat pemancingan, taman bunga anggrek dan tempat bermain anak.

4) Membangun dan mengadakan aksesibilitas wisata

Aksesibilitas adalah semua faktor yang dapat memberi kemudahan kepada wisatawan untuk berkunjung ke daerah tujuan wisata seperti: seperti tersedianya prasarana bandara, pelabuhan, terminal, stasiun kereta api, terminal, prasarana jalan, jembatan, dan trasportasi. Berdasarkan hasil interview dan survei lapangan menunjukkan bahwa belum tersedia transportasi umum menuju lokasi wisata Kum Kum. Jika wisatawan ingin mengunjungi objek wisata ini, transportasi yang bisa digunakan oleh wisatawan dari luar daerah adalah persewaan mobil, ojek, dan taksi.

\section{b. Strategi WO (Weaknesses and Opportunities)}

Strategi WO (Weaknesses and Opportunities) yaitu strategi yang meminimalkan kelemahan (Weaknesses) dengan memanfaatkan peluang (Opportunities) adalah:

1) Meningkatkan promosi dan memperbaiki program pengembangan lebih bagus untuk menarik pengunjung sehingga siap untuk menghadapi persaingan antar objek wisata

Promosi merupakan suatu cara atau strategi yang dilakukan oleh perusahaan untuk memperkenalkan produknya kepada khalayak ramai. Strategi meningkatkan promosi dimaksudkan untuk memanfaatkan peluang yang ada dalam mengurangi kelemahan belum berkembangnya suatu objek wisata. Salah satu promosi yang bisadilakukan adalah melalui mediaelektronik, surat kabar, spanduk dan pamflet.

2) Melakukan koordinasi dengan pihak swasta dan pemerintahan untuk menanamkan modal Strategi ini dilakukan untuk mendukung kelanjutan pembangunan agar dapat membantu membangun sarana prasarana, akomodasi, atraksi objek wisata pendamping dan sarana lainnya yang belum tersedia. Untuk itu diperlukan koordinasi guna menarik minat investor atau pihak swasta dan pemerintah. Koordinasi dengan pihak swasta untuk menanamkan modalnya dengan membentuk kerjasama atas dasar kesepakatan dan rasa saling membutuhkan untuk meningkatkan kapabilitas dalam bidang pariwisata. 
Jurnal Pendidikan Geografi:

Kajian, Teori, dan Praktik dalam Bidang Pendidikan dan Ilmu Geografi

Tahun 23, Nomor 2, Jun 2018, Hal 94-106

\section{c. Strategi ST (Strength and Treats)}

Strategi ST (Strength and Treats) yaitu strategi yang mengunakan kekuatan (Strength) untuk mengatasi ancaman (Treats) adalah:

1) Mengoptimalkan potensi alam dan keunikan objek wisata dengan mempertahankan dan pemeliharaan objek wisata secara berkesinambungan untuk menghadapi persaingan antar objek wisata.

2) Pengembangan dan pembangunan objek wisata yang ramah lingkungan dengan melakukan kontrol yang tegas terhadap pelaksanaan unsur-unsur pelaku wisata yang tidak sesuai dengan sikap dan tindakan pelaku wisata yang dapat mengancam kerusakan objek wisata

3) Mengadakan objek wisata pendamping

\section{d. Strategi WT (Weaknesses and Treats)}

Strategi WT (Weaknesses and Treats) yaitu strategi yang meminimalkan kelemahan (Weaknesses) dan menghindari ancaman (Treats) adalah:

1) Peningkatan kualitas tenaga kerja professional dalam pengelolaan dan pemeliharaan objek wisata secara berkesinambungan sehingga mengu-rangi kerusakan lingkungan.

2) Melakukan pengawasan dan pemeli-haraan fasilitas-fasilitas yang telah ada dilokasi objek wisata.

\section{KESIMPULAN}

Kawasan taman wisata Kum Kum di Kota Palangka Raya merupakan kawasan wisata dengan daya tarik something to see berupa pemandangan alam, dan kebun binatang mini, something to do berupa aktivitas bermain di taman, dan bersantai di gazebo, sedangkan something to buy berupa warung makan.

Strategi pengembangan taman wisata Kum Kum antara lain membangun sarana prasarana seperti alat angkut dan sarana akomodasi, mengembangkan produk wisata, dan bekerjasama dengan pihak swasta dan pemerintah untuk menanamkan modal. Jika kekuatan dan peluang ditingkatkan serta meminimalkan kelemahan dan menghindari ancaman dilakukan oleh pengelola dan didukung oleh penerapan strategi pengembangan yang tepat, maka taman wisata Kum Kum yang terletak di Kota Palangka Raya Kalimantan Tengah ini akan mampu bersaing dengan objek wisata lainnya yang ada di Kota Palangka Raya bahkan di Propinsi Kalimantan Tengah.

\section{DAFTAR RUJUKAN}

Andayani, Sriyanti, dkk. tt. Pengembangan Kawasan Wisata Balekambang Kabupaten Malang. Jurnal Rekayasa Sipil, 6 (2): 168-178.

BPS. 2010. Berita Resmi Statistik No. 12/02/Th. XIII. Diakses Januari 10, 2017, dari BPS: http://www.bps.go.id/ brs_file/pdb-10feb10.pdf

Farhanudin, Evan. 2012. Analisis Strategi Pemasaran Objek Wisata Danau Tasikardi oleh Dinas Pariwisata Pemuda dan Olahraga Kabupaten Serang. Serang: Skripsi Fakultas Ilmu Sosial dan Ilmu Politik Universitas Sultan Ageng Tirtayasa.

Garrod, B \& Wilson. 2003. Marine Ecotourism: Issuee and experiences. Sydney, Australia: Channel View Publications.

Hadioto, Kusudianto. 1996. Perencanaan Destinasi Pariwisata. Jakarta: Universitas Indonesia. 
Jurnal Pendidikan Geografi:

Kajian, Teori, dan Praktik dalam Bidang Pendidikan dan Ilmu Geografi

Tahun 23, Nomor 2, Jun 2018, Hal 94-106

Hermawan, Heri. 2008. “Analisis Pengembangan Kebijakan Pariwisata Indonesia (Studi Perbandingan Kebijakan Pariwisata Indonesia dengan Malaysia)". Jurnal Kepariwisataan Indonesia, 3 (1): 13-35

Maryam, Selvia. 2011. Pendekatan SWOT dalam Pengembangan Objek Wisata Kampoeng Djowo Sekatul Kabupaten Kendal. Semarang: Skripsi Fakultas Ekonomi Universitas Diponegoro.

Miradona, Yurieni, dkk. 2013. Analisis Pengelolaan Untuk Meningkatkan Upaya Konservasi Di Taman Margastwa Dan Budaya Kinantan Kota Bukittinggi. Jurnal BIOLOGIKA, 2 (1): 7-17

Pendit, Nyoman. 2002. Ilmu Pariwisata : Sebuah Pengantar Perdana . Jakarta: PT Pradnya Paramiata.

Perda Kota Palangka Raya Nomor 11 Tahun 2017 Tentang Rencana Induk pembangunan Kepariwisataan Kota Palangka Raya Tahun 2017-2028.

Prasta, Aditia. 2003. Arahan Pengembangan Kawasan Pariwisata Cibodas Berdasarkan Konsep Ekowisata. Bandung: Tugas Akhir Departemen Teknik Planologi ITB.

Putri, T dan Ariani, M. 2011. "Penerapan Sadar Wisata dan Penguatan Citra Wisata Melalui Penanaman Tanaman Upakara di Kerambitan Kabupaten Tabanan". Jurnal Udayana Mengabdi, 10 (2): 90-94

Roostika, Ratna. 2012. "Citra Merek Wisatadan Perilaku Wisatawan: Yogyakarta sebagai Daerah Tujuan Wisata". Jurnal Manajemen dan Akuntasi, 1 (1): 41-54

Bappeda Kota Palangka Raya. 2011. Selayang Pandang Kota Palangka Raya. Palangka Raya: Bappeda

Undang-Undang RI Nomor 32 Tahun 2004. Tentang Pemerintah Daerah. Jakarta

Wahab, Salah.1997. Pemasaran Pariwisata. Jakarta : PT. Pradnya Paramitha.

Wasistiono, Sadu, dkk. 2007. Prospek Pengembangan Desa. Bandung: CV. Fokusmedia.

Yoeti, Oka. 1996. Pengantar Ilmu Pariwisata. Penerbit Angkasa: Bandung. 